Kuswandi, Ph.D. of Economics, Associate Professor of Sekolah Tinggi Ilmu Ekonomi Mahardhika, Surabaya,

ORCID ID: 0000-0002-3186-371X

e-mail: kuswandistie@gmail.com

Asmirin Noor, Ph.D. of Economics, Sekolah Tinggi Ilmu Ekonomi Mahardhika, Surabaya, Indonesia

ORCID ID: 0000-0003-4925-8451

e-mail: asmirinstie@gmail.com

Siti Mahmudah, Ph.D. of Economics, Sekolah Tinggi Ilmu Ekonomi Mahardhika, Surabaya, Indonesia

ORCID ID: 0000-0002-5475-5359

e-mail: sitimahmudahstie@gmail.com

Martin Zebua, Master of Economics, Sekolah Tinggi Ilmu Ekonomi Mahardhika, Surabaya, Indonesia

ORCID ID: 0000-0001-6576-8246

e-mail: martinzstie@gmail.com

\title{
The Role of Political Will and Organizational Culture toward Iron and Steel Company Competition
}

Abstract. Introduction. Culture and political will were the weak points of Indonesian company. This was seen through steel and iron company in Indonesia which could not compete as well as China, Korea, Japan, and India. It proved that government did not possess a strong capability in enhancing manufacturing. Organizational culture also contributed to value change, creativity, manner, perception, innovation and willing to take a risk.

Purpose. This study aimed to reveal the inability of price fixing competition and to manage product quantity produced by the company.

Results. The qualitative explorative method was used to collect data while the instruments were survey, observation, interview, and documentation of the company registered at IISA (The Indonesian Iron \& Steel Association). The findings revealed that the problems were caused by (1) a difference in political wills in central and regional governments; (2) The policy could not afford an easier administration process; (3) Dwelling cost for imports; (4) The manufacture interest was above 12\%; (5) Intensive fund which was not rising; (6) lack of investment stimuli; (7) Dwelling time was still more than 5 days.

Conclusions. There was no significant change that reduces the operational cost of iron and steel manufacturing, also no significant impact on price fixing and quantity production of the companies.

Keywords: cultural aspect, organizational culture, political will, IISA, steel and iron company

удК: 338

Кусванді, кандидат економічних наук, доцент, Sekolah Tinggi Ilmu Ekonomi Mahardhika, Сурабая, Індонезія

Асмірін Ноор, кандидат економічних наук, Sekolah Tinggi Ilmu Ekonomi Mahardhika, Сурабая, Індонезія

Сіті Махмудах, кандидат економічних наук, Sekolah Tinggi Ilmu Ekonomi Mahardhika, Сурабая, Індонезія

Мартін Зебуа, магістр економіки, Sekolah Tinggi Ilmu Ekonomi Mahardhika, Сурабая, Індонезія

\section{Роль політичної волі та організаційної культури у конкуренції залізної та металургійної компаній}

Анотація. Культура і політична воля були слабкими сторонами індонезійської компанії. Це сталося через сталеву та залізну компанію в Індонезії, яка не могла конкурувати так само як Китай, Корея, Японія та Індія. Доведено, що уряд не володів сильною спроможністю посилювати виробнищтво. Організаційна культура також сприяла зміні цінності, творчості, манері, сприйняттю, інноваціям і бажанню ризикувати.

Дослідження спрямоване на виявлення неспроможності встановлення цінової конкуренції та управління кількістю продукції, що виробляється компанією.

Для збору даних використовувався якісний дослідницький метод, інструменти дослідження - обстеження, спостереження, інтерв'ю та документація компанії, зареєстрованої в IISA (Індонезійська асоціація заліза та сталі). Результати свідчать, що проблеми були викликані: 1) різницею в політичній волі центральної влади та регіонального уряду; 2) політика не могла дозволити простіший процес адміністрування; 3) вартість житла для імпорту; 4) інтерес виробництва був вище 12\%; 5) інтенсивний фонд, який не зростав; 6) відсутність інвестиційних стимулів; 7) час проживання був більше 5 днів.

Стаття надійшла до редакції: 06.06.2019

Received: 6 June 2019 
Встановлено, що не було значних змін, які б зменшили експлуатаційні витрати на виробництво чавуну і сталі, а також не мало значного впливу на фіксацію цін і масове виробництво компаній.

Ключові слова: культурний аспект; організаційна культура; політична воля; IISA; металургійна компанія.

Statement of Problem. The company of steel and iron is the main industry that contributes greatly to the development of the manufacturing industry. This company exerts control over other industries as it supplies the basic material for most industries, such as infrastructure, transportation, manufacturing, and military industries. Annually, Indonesia consumes 17.46 tons of steel and iron. Meanwhile, its production capacity is only have limitation on 14 tons per year. In order to increase the production rate, the government should take action in both political and cultural realms. The Indonesian government possesses an absolute authority to give protection for the iron and steel industries. According to a policy made by the World Trade Organization (WTO, 2013), the production rate of industries could be improved as long as the price is still on the dumping level. Moreover, the SNI (Indonesian Standard) certification should give maximum contribution. Thus, the quality and quantity of the imported products undergo a tight process of selection.

Moreover, the combination of political will and organizational culture is enhancing the capability of human resources to work with high motivation under high demands. Thus, the bond between the company and its workers would tighten along with the industries' growth, even though the development among workers varies (Susanto, 1997). Corporate culture is a cognitive framework which contains attitude, manner, norms, and faiths (Grenberg and Baron, 1977). Culture is defined as a form of cognition, manner, attitude, feeling, and style of attitude. In price fixing among international competitors, the government could help the industries by subsidising the import tax and cooperating stimulation of export. That is why other countries, such as China, have lower prices than Indonesia. This study aimed to reveal how Indonesian price fixing became low and the quantity of production rate was reduced the import activity. According to present political will and organizational culture, there were several problems: 1) anti-dumping import tax 2) the difficulties in documentation process 3 ) intensive tax for importing materials 4) no continuity of stimulus education.

In 2013, the consumption rate of steel and iron reached 12.7 tons or $15.1 \%$ per year (World Steel Association, 2014). In order to enhance the production rate, Corporate Culture was needed as the instrument in overcoming primary problems. If the organization support presented a huge motivation to follow the policy, then the problem would be overcome quickly and efficiently (Koesmono, 2005). While in overcoming high consumption rate of iron and steel in Indonesia along with national iron and steel production, the productivity was still imported from other countries. From 2010 to 2014, the total import of steel and iron was significantly growing around $10.40 \%$ or 14.16 million tons each year, which cost for USD 12.65 billion at the end of 2014.

Analysis of Recent Research and Publication. According to previous study, there was no government acts in giving huge contribution in the development of industries. Government took a long time on the process of licensing, incentive manufacture, and loan and customs policy, which affected on production rate and price fixing. The high price given by industries was coming from the high operational and the duration of licensing that resulted in different price fixing. The failure of government in giving support and protection for the industries was indicated by the bankrupt of $30 \%$ steel and iron industries in 5 years. According to Gapbesi (Association of Iron Industrialist) data, there were 201 industries fully operated in 2001. However in 2006, the number was decreasing to 134 industries (Anonymous, 2007). Moreover, the imported steel volume in 2006 from China was USD 1.68 billion and increase for USD 4.2 billion in 2016. At this point, government needed to reconsider the policy for importing the basic materials for industries such as faro nickel, copper, silicon, and iron seed. In the other hand, illegal import of iron and steel could also disadvantages the National Industries of iron and steel.

Setting Objectives. This study aimed to reveal the inability of price fixing competition and to manage the products quantity produced by the company.

The main part. Organizational Culture. According to Davis and Newtrom, cited on Mangkunegara, organizational culture is a set of assumptions, believes, values, and norms that shared among its members (Mangkunegara, 2008). Hunt, as cited on Mangkunegara, stated that organizational culture is the system of shared beliefs and values that develops within an organization and guides the behaviour of its members (Mangkunegara, 2008). They agreed that the better the organizational culture, then the better the work earned. But the worse the organizational culture, the worse the work rates gained. Organizational culture had three important functions, those were; watch out system, social interaction, and understanding value. Thus, organizational culture must be adaptive and dynamic toward working environment.

For long term work rates, organizational culture became a tool of the industry to achieve the vision and mission. It had function as demand for the workers to give their best contribution for the development of the industry (Gomez, 2011). The effective organizational culture could face new challenges from outside and able to respond changes of globalization (Kotter \& Hesket, 1997). The maximum functions of organizational culture will drive workers to achieve expectation within positive manner and well-organized contribution. The problems among steel and iron industries would be analysed from organizational culture, including managers, workers, and 
users. According to Walker, there were several characteristics of organizational culture; those were 1) innovation and risk taking, 2) detail attention, 3) outcome orientation, 4) people orientation, 5) team orientation, 6) aggressiveness, and 7) stability (Walker, 2015). Robert and Angelo claimed that there were three important aspects of organizational culture, those were; organizational culture is given through socialization, organizational culture gave significant impact in working environment, and organizational culture provided high quality service, such as customer service's quick respond (Abdullah, 2010).

Political Will. Political will which became the focus in this study was incentives and disincentive of government policy. This policy was talked about the possibility in supporting the national steel and iron's company. It was a commitment, involvement and continuous strength of government or administrator to support and invest the useful source to achieve a certain goal to make and implement political policy. Political will was a good governance which needed a strength, effective government, and active involvement of other countries and social organizations (Hyden, Court, and Mease, 2004). Actually, making steel and iron's industry as one of the economic foundation in Indonesia was leading to conflict on political will, such as the confusion in accomplished main priority among unemployment policy, educational policy, poverty policy, or manufacture policy.

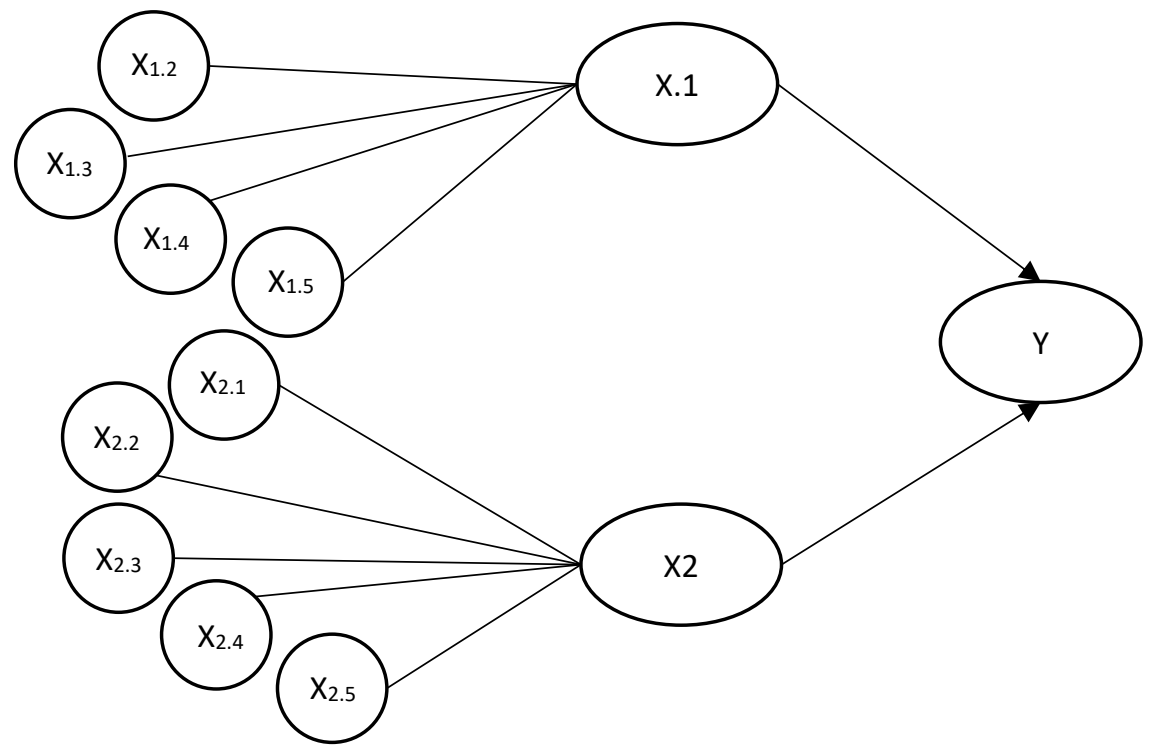

Fig 1. Conceptual Mind Mapping

Source: own study

Table 1. Description of structure

\begin{tabular}{|l|l|}
\hline \multicolumn{1}{|c|}{ Political Will } & \multicolumn{1}{|c|}{ Organizational Culture } \\
\hline X1.1 Government Initiation & X2.1 Value Change \\
X1.2 Examination Priority & X2.2 Aggressive \\
X1.3 Political Mobility & X2.3 Integrity \\
X1.4 Upholding Law & X2.4 Innovation \\
X1.5 Consistency & X2.5 Risk Taking \\
\hline
\end{tabular}

Source: own study

The concepts and practices of government initiation or participatory policies had broad and complex concepts in differentiating policies on public ways of translating and interpreting the policy. Initiative or participative government had advantages in policy when public were involved. The advantages covered the enhancement of government management and good development of society empowerment. These were very important in building political will in which government brought direct and significant advantages in the implementation.
Methodology. This study used descriptive explorative methodology by interviewing the sample. The sample were consisted of 4-5 staffs posed bachelor degree and 47 managers of steel and iron company of IISA members, including Krakatau Steel, Barata Indonesia, Ispatindo, Jaya Pari, Baja Tama, Gunawan Dianjaya Steel, Steel Pipe Industry of Indonesia and Lion Metalwork). This study used qualitative approach with analysing technique using hierarchy linear approach, built from bottom to top (workers to managers). 
Result. The result of the study was shown in five aspects; political initiative, analyse priority, political mobility, upholder law, and consistency. Political initiative of Indonesian Government was known as solid support from government to business actors to improve the production rates and price fixing of iron and steel. In fact, Indonesian government was still focusing on infrastructure development with assumption on the lack of steel and iron. Hence importing materials from China, Japan, South Korea, and India was still done. Therefore it could be said that the result of Indonesia political initiative to support steel and iron was failed.

The second was analysing the priority. In this case, the government still could not determine the priority that should precede other aspects, such as education, health, social, or poverty. Based on the interview, the priority for iron and steel industries were still far from target. It was seen on the documentation and licensing process that still take much time. The third was political mobility support. It was seen as the relation between the government and legislative assembly. The successfulness of this aspect could be seen from the quantity of iron and steel. If the mobility support was released, the number of iron and steel must be able to cover the national need. There must be a contribution from society in establishing the policy concerning on private and state sector of iron and steel industries. The reality in Indonesia showed that the quantity of iron and steel were on shortage condition which described that government had complicated and unfixed leadership.

The next aspect was the upholding law. The upholding law here was defined as the government political will in issuing policy for infestation licensing, material import, customs licensing. Government had crucial role in this aspect, such as government should able to manage and responsible in finding illegal cost while importing or exporting materials. The sanction for this action should be firm within maximum punishment. Thus, there must be visibility among all actors of state and industries to achieve independence and growing development of steel and iron industries. The fifth aspect was the consistency of government to support iron and steel industries. The fifth aspect was significantly good in Indonesia. Within several years, the consistency of Indonesian government to support the quantity, quality, technology, innovation, and primary service were continuous.

Meanwhile, seeing the political will of current Indonesian government in Indonesia was still very low. For example the initiative of power politics where the government program is more inclined to infrastructure, including priority study of whether infrastructure development could reduce the dependence of national iron and steel import as great value over the next 3-4 years except in the indicator of existence. Different with the political will of China, Japan, South Korea and India which adopted policy on manufacturing industry, such as law enforcement, tax incentives, service, high technology and innovation.
Positive Phenomenon. The result of the study showed that a good political will could help building the downturn of price fixing or production rates in iron and steel industries. As what Schuler and Jackson (1997) said that the better the political will, the better the production rates. While the worse the political will, then the worse the production rates. The impact could be seen on the regulation change of some policies in industrial process. The policies such as incentive tax, customs policies, organizational structure, and infrastructure, would had significant impact on dwelling time process. Good organization could also reduce operational cost of iron and steel industry in exporting or importing materials. Moreover, digitalizing some device would help the process to cut the dwelling time process.

Meanwhile, the positive phenomenon of organizational culture was seen as spreading system of faith and the values that developed within an organization (Schuler \& Jackson, 1997). If organizational cultures succeed in bounding its workers, then it would create better environment for the industry development. This meant that the better the quality of organizational culture, the better the working performance will be. Organizational culture which cope on some individuals or groups within an iron and steel manufacturing company, that has an indicator of personal and group innovation, was dare to take a risk in making decisions that has potential to generate dynamics within the company. An organization could also form the behaviour for members as well as be able to improve competitiveness with companies from overseas such as China, South Korea, Japan and India (Mangkunegaran, 2008). Interview data on organizational culture variables that have indicators of creative attitude, innovation and integrity have the ability to increase productivity. Thus it could be able to face global competition, especially from China, South Korea, Japan and India. The lack of creative attitude, innovation and high integrity cause decreasing ability of competing power and having no high productivity. This is supported by the opinion of Kotter \& Hesket (1997) that the freedom of innovation could affect the opportunity for individuals to work. Miller (1987) stated that organizational culture of manufacturing companies consisted of familiarity, integrity, and superiority to improve productivity.

Practical Implication. The next finding was about practical implication. Some implication of political will was concerning on Political Initiative, Analyse priority, Political Mobility, Upholder Law, and Consistency. These all elements would support the development of industry such as political party, government, stakeholders, and the actors on the field should possess high integration and obey the order. It would not give significant burden for industries to run their operation. Unfortunately, the fact showed that the contribution of government in political will is still low. This condition would not give great impact in the development of industry of iron and steel of Indonesia (IISA) (Markusen et al, 1996). 
The indicators of organizational culture are value change, creativity, high integration, innovative, and risk taking. These aspects would greatly improve working performance among the staff. Based on the result of interview, some factories approve the usefulness of organizational culture when they apply some method for the workers. For example, rewards and commitment are simple way to manage and dope the workers to achieve the goal of company. Moreover, some companies also apply some events that give motivation and spiritual improvement such as outbound while they are not on working time (La Belle, 2005).

Conclusion. In conclusion, political will which contained with political initiative, analyse priority, political mobility, upholder law and consistency was not at the maximum capacity since the dwelling time were still the same. There was no such significant change that reducing the operational cost of iron and steel manufactures. In order to overcome the problem, two aspects were becoming government's main focus, those were; licensing process and incentive tax.

Organizational culture which consisted of value change, creativity, high integration, innovative, and risk taking was not able to maintain the development of manufacture environment. There was no significant impact that could be seen on price fixing and quantity production of the companies. However, some valuable variables that could enhance the productivity of iron and steel, by giving ice breaking time for the workers, such as rewards and outbound, were found. These valuable variables created the development on workers' characterization, attitude, and commitment.

Acknowledgement. The authors declare that they have no financial or personal relationships which may have inappropriately influenced them in writing this article.

\section{References:}

1. Abdullah, H. A. (2010). Pengaruh Budaya Organisasi, Komitmen Organisasi dan Akuntabilitas Publik terhadap Kinerja Organisasi. Jurnal Ekonomi dan Bisnis, 9(2), 118-134.

2. Anonymous (2007). Industri Baja Nasional dalam Konsolidasi Global. Media Relation. Retrieved from http://krakatausteel.com/index.php?page=viewnews \&action=view\&id268.

3. Gomez-Mejia, L. R., Balkin, D. B., \& Cardy, R. L. (2007). Managing human resources. Upper Saddle River, New Jersey: Pearson/Prentice Hall.

4. Greenberg, J., \& Baron, R. A. (1997). Behavior in organizations: Understanding and managing the human side of work. Upper Saddle River, New Jersey: Prentice Hall.

5. Hydén, G., Mease, K., \& Mease, K. (2004). Making sense of governance: empirical evidence from sixteen developing countries. Lynne Rienner Publishers

6. Kotter J. P., \& Heskett J. L. (1998). Corporate Culture and Performance. Jakarta: Prehallindo.

7. LaBelle, J. E. (2005). The Paradox of Safety Hopes \& Rewards: Are you rewarding the right behavior? Professional Safety, 50 (12), 37.

8. Mangkunegara, A. A. (2008). Perilaku dan Budaya Organisasi. Bandung: Refika Aditama.

9. Markusen et al. (1996). International Trade Theory and Evidence. United States: McGraw-Hill.

10. Miller, L. M. (1987). Manajemen Era Baru: Beberapa Pandangan Mengenai Budaya Perusahaan Modern. Jakarta: Terjemahan, Erlangga.

11. Susanto, A. B. (1997). Budaya Perusahaan: Seri Manajemen Dan Persaingan Bisnis. Cetakan Pertama, Elex Media Komputindo, Jakarta.

12. Schuler, R. S., \& Jackson, S. E. (1997). Manajemen Sumber Daya Manusia Menghadapi Abad Ke-21. Jakarta: Erlangga.

13. Walker, R. (2014). Strategic management communication for leaders. Nelson Education.

14. Widodo. (2011). Pengaruh Budaya Organisasi dan Motivasi Kerja terhadap Kinerja Guru. Jurnal Pendidikan Penabur. 6(2): 45-50

15. WTO. (2013). Agreement on Implementation of Article VI of the General Agreement on Tariffs and Trade 1994 (Anti-Dumping Agreement).

Ця робота ліцензована Creative Commons Attribution 4.0 International License 